\title{
Production of Hydrogen from Poly Ethylene Terephthalate (PET) using CT 434 ZSM-5 Catalyst at Considerably Low Temperatures
}

\author{
Abdulaziz H. El-Sinawi \\ College of Engineering \\ King Faisal University \\ Saudi Arabia \\ aelsinawi@kfu.edu.sa
}

\begin{abstract}
The production of hydrogen from Poly Ethylene Terephthalate (PET) using CT 434 ZSM-5 is investigated in this research study. Gas chromatography equipped with a thermal conductivity detector is used to detect the amount of hydrogen produced at different temperatures. The Chromatograph spectrum of pure hydrogen as well as the spectra of evolved gases at $250^{\circ} \mathrm{C}, 280^{\circ} \mathrm{C}, 310^{\circ} \mathrm{C}$ and $340^{\circ} \mathrm{C}$ are obtained to validate the presence of hydrogen. The spectra of percentage of hydrogen and peak area to height ratio with increasing temperature shows a similar trend except at the temperature of $340^{\circ} \mathrm{C}$. Maximum hydrogen percentage of $20.11 \%$ is found in the evolved gases collected at temperature of $250^{\circ} \mathrm{C}$. The retention time of sample collected at $340^{\circ} \mathrm{C}$ is very close to reference retention time 2.014 min observed for a pure hydrogen sample.
\end{abstract}

Keywords-hydrogen; Poly Ethylene Terephthalate (PET); Gas Chromatograph (GC); Thermal Conductivity Detector (TCD)

\section{INTRODUCTION}

The production of hydrogen has recently attracted the attention of scientists and researchers due to the increase in energy consumption to commensurate the rapidly growing technology and the dramatically increase in population. Among different energy sources, the most popular and widely used energy source is fossil fuels. Considering the over consumption, the decrease in the available stock and the high emissions of carbon dioxide, hydrogen may be an ideal candidate to be used as a greener energy. The production, storage and transport of hydrogen in an economical and safer way are major challenges for hydrogen to replace other sources of energy. Today's generation of hydrogen from hydrocarbon based compounds and derivatives are very popular [1-6]. Hydrogen can also be produced by a steam reforming process. Presently, a famous industrial process for the production of hydrogen is steam reforming of natural gas using methanol and ethanol as raw materials [7-9]. Gases may be produced from the solid wastes first and then a steam-reforming process can be employed for hydrogen production [10]. Recently a process to produce hydrogen from polyethylene (PE) milled with nickel hydroxide and calcium hydroxide was reported [11]. Nickel hydroxide was dispersed completely among the samples converted to nickel metal during the heating process that act as catalyst to enable the conversion. Calcium hydroxide fixed the carbon dioxide and allowed the production of hydrogen in high purity. Production of hydrogen from PET (C10H8O4) using a CT 434 ZSM-5 catalyst may provide an easy and sophisticated procedure to get hydrogen that can be used as green energy in the future.

In this paper the production of hydrogen gas from PET using a CT 434 ZSM-5 catalyst at various temperatures is studied. A PerkinElmer Clarus 580 gas chromatograph with a built-in auto-sampler equipped with a thermal conductivity detector had been used to detect the evolved hydrogen as a result of reaction.

\section{EXPERIMENTAL SET-UP}

\section{A. Materials}

A list of the materials used is given below:

- Polyethylene Terephthalate (PET) square shape pieces $(1 \mathrm{~cm} \times 1 \mathrm{~cm}): 20 \mathrm{gm}$

- $\quad$ CT 434 ZSM-5 catalyst powder: 10gm

- $\quad$ Electric heater

- Five air tight glass vials with rubber lids for hydrogen samples collection

- $\quad$ Three necked (flanges) round bottom flask

- An ebro TCL 730 infrared thermometer with readings up to $350^{\circ} \mathrm{C}$

- $\quad$ Plastic tubes of $20 \mathrm{~cm}$ length with external diameter $3 \mathrm{~mm}$ and internal $2 \mathrm{~mm}$ having syringe needles on one end

- A gas tight glass Syringe for sample collection

- Hydrogen (H2): purity $>99.99 \%$

- $\quad$ Nitrogen (N2): purity $>99.99 \%$ 


\section{B. Instrument}

A PerkinElmer Clarus 580 gas chromatograph with thermal conductivity detector with a built in auto-sampler and a data acquisition system was used. A typical schematic diagram of the gas chromatograph (GC) system is shown in Figure 1.

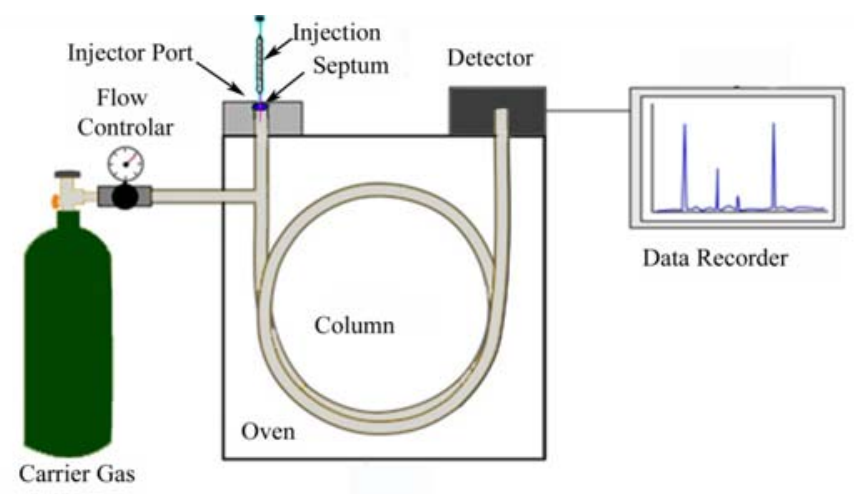

Fig. 1. A typical schematic diagram of a gas chromatograph with a thermal conductivity detector.

\section{Method-Sample Collection}

Small pieces of Polyethylene Terephthalate (PET) are obtained by cutting empty Nestle mineral water plastic bottles in Square shapes of $1 \times 1 \mathrm{~cm}$. These pieces are washed with boiling water and dried using an air drier. The round bottom flask with three flanges is used as a reactor. A sample of $20 \mathrm{gm}$ of those pieces are placed in the reactor. CT $434 \mathrm{ZSM}-5$ catalyst powder $10 \mathrm{gm}$ is dispersed almost uniformly among the plastic pieces. An Ebro TCL 730 infrared thermometer is fixed into the central flange of the reactor to record the temperature of the reactor. The thermometer is adjusted very carefully to read the temperature easily at different instants of time during the experiment. A glass capillary tube with a valve is open into the reactor through one of its flanges. A plastic tube with an internal diameter of $5 \mathrm{~mm}$ and external diameter of $7 \mathrm{~mm}$ having a syringe needle on its one end is fixed on the open end of glass capillary tube. The syringe needle is inserted into the glass vial. This vial is equipped with a purging valve. The third flange also has a valve to purge out the residual gases in the reactor before collecting the hydrogen gas sample.

The reactor with above said arrangements is placed on an electric heater as shown in Figure 2. Electric power is turned on to start the heating process. It takes nearly 10 minutes to start the reaction between the PET pieces and the CT434 ZSM-5. Gases are evolved as a result of reaction with heating. These evolved gases can easily be observed. After few minutes, pressure is developed by the evolved gases and the air already present in the reactor. To minimize the presence of air in the reactor, the purging valve of third flange of reactor is opened and gases are released out freely. Gases were purged out of the reactor several times using the purging valve to minimize the presence of air in the reactor. When the temperature rises up to $230^{\circ} \mathrm{C}$, the valve of the capillary tube is opened and gas is allowed to rush to the vial. After some time, when a sufficient amount of evolved gases is accumulated, the vial is purged and evacuated several times to ensure that no air or any other gases are accumulated before collecting the actual hydrogen samples. When temperature reaches $250^{\circ} \mathrm{C}$ the first evolved gases sample was collected by closing the purging valve. This sample of evolved gas is considered to be taken at $250^{\circ} \mathrm{C}$ for the convenience of analysis purpose. Similarly another vial is evacuated several times and then filled with evolved gases at $280^{\circ} \mathrm{C}$. The same procedure was followed to collect two other samples at $310^{\circ} \mathrm{C}$ and $340^{\circ} \mathrm{C}$ respectively. The schematic diagram of experimental arrangements of the rector for hydrogen production and collection is shown in Figure 2.

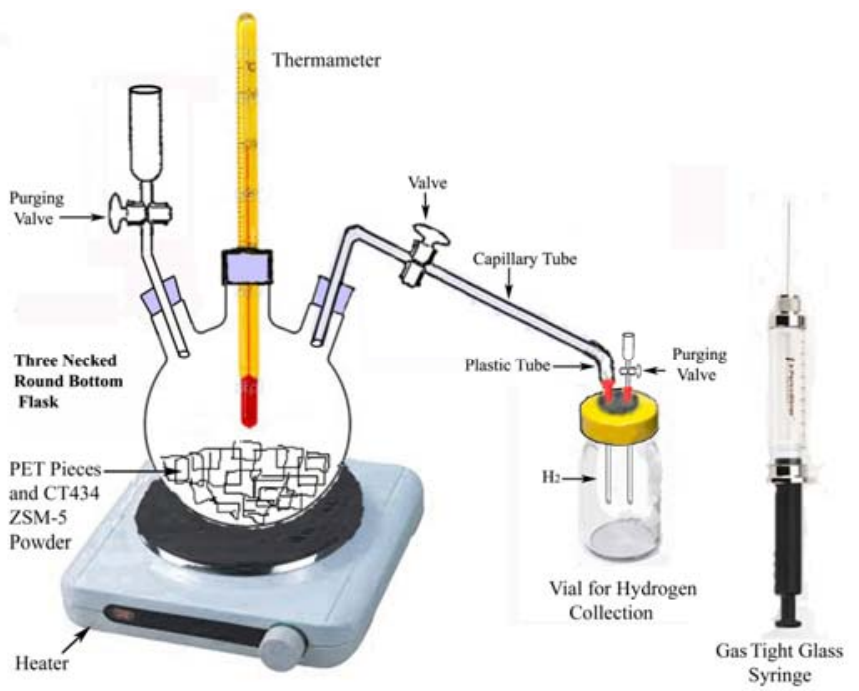

Fig. 2. A schematic diagram of experimental arrangements of the reactor for hydrogen production and collection

\section{Gas Chromatography}

- Experiment is conducted with Injector temperature of $150^{\circ} \mathrm{C}$.

- Volume of $1 \mathrm{ml}$ produced hydrogen was collected from each sample at $250^{\circ} \mathrm{C}, 280^{\circ} \mathrm{C}, 310^{\circ} \mathrm{C}$ and $340^{\circ} \mathrm{C}$.

- $\quad$ Each sample was manually injected through a septum with a gas tight syringe.

- Approximately $99.99 \%$ pure commercially available Nitrogen is used as carrier gas with flow rate of $8.0 \mathrm{ml} / \mathrm{min}$.

The Gas chromatograph system was calibrated using pure hydrogen, hence $1 \mathrm{ml}$ volume was injected manually into the injector port through septum using the gas tight syringe. The spectrum of pure hydrogen was obtained for reference, then 1 $\mathrm{ml}$ of the collected gas samples from the reactor were analyzed at different temperatures $\left(250^{\circ} \mathrm{C}, 280^{\circ} \mathrm{C}, 310^{\circ} \mathrm{C}\right.$ and $\left.340^{\circ} \mathrm{C}\right)$ respectively. Spectra for gas samples collected at $250^{\circ} \mathrm{C}$, $280^{\circ} \mathrm{C}, 310^{\circ} \mathrm{C}$ and $340^{\circ} \mathrm{C}$ was obtained for analysis. The sampling syringe had been purged several time to remove any residual gas from the previous runs. 


\section{RESUlTS AND DisCUSSION}

The statistical data for the calibration curve is shown in Table I. Table I shows the experimental results of the mean hydrogen peak areas for injected volume of $0.5-2.5 \mathrm{ml}$ pure hydrogen. Figure 3 shows the linear fit of the peak points versus volume of injected hydrogen. It is clearly observed that the thermal conductivity response to the increasing volume of the injected hydrogen is approximately linear.

TABLE I. STATISTICAL DATA OF INJECTED HYDROGEN AND PEAK AREA

\begin{tabular}{|c|c|c|}
\hline No & Injected Volume (ml) & Peak Area $(\boldsymbol{\mu V S})$ \\
\hline 1 & 0.5 & 43739.4 \\
\hline 2 & 1 & 87613 \\
\hline 3 & 1.5 & 133864.8 \\
\hline 4 & 2 & 201141.12 \\
\hline 5 & 2.5 & 295130.14 \\
\hline
\end{tabular}

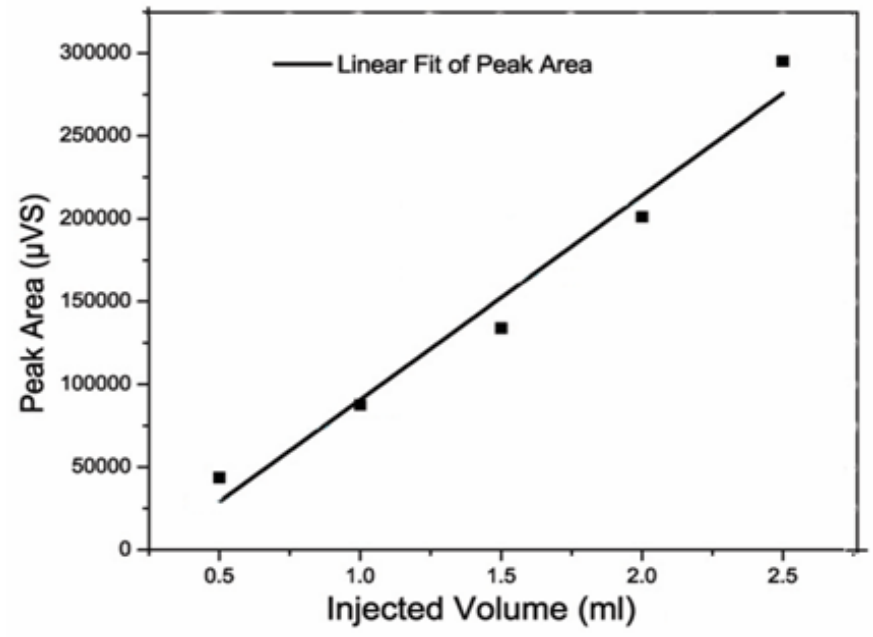

Fig. 3. Linear fit of the peak area versus volume of pure hydrogen

The reference spectra of pure hydrogen and the other spectra of collected samples of evolved gases at different temperatures, $250^{\circ} \mathrm{C}, 280^{\circ} \mathrm{C}, 310^{\circ} \mathrm{C}$ and $340^{\circ} \mathrm{C}$ are shown in Figure 4. The retention time of pure hydrogen is observed at $2.014 \mathrm{~min}$. The appearance of hydrogen spectra of evolved gas samples at nearly the same retention time indicates the production of hydrogen as a result of pyrolysis reaction of PET1 in the presence of the CT434 ZSM-5 catalyst.

The variation in retention time (peak position) versus the temperature of the reactor during the process is described in Figure 5. The retention time for a sample taken at $250^{\circ} \mathrm{C}$ is $2.025 \mathrm{~min}$ and reached to the maximum of $2.029 \mathrm{~min}$ at $275^{\circ} \mathrm{C}$ whereas the retention time of hydrogen gas did not stay at the maximum for a long time, hence it decreased slightly to 2.027 min at $310^{\circ} \mathrm{C}$. This deceasing trend continues to a minimum value of $2.015 \mathrm{~min}$ at $340^{\circ} \mathrm{C}$, which is very close to the reference retention time of pure hydrogen (i.e. $2.014 \mathrm{~min}$ ). It was observed that at higher temperature than $310^{\circ} \mathrm{C}$, the collected hydrogen has similar trend as that of pure hydrogen with retention time of $2.014 \mathrm{~min}$.

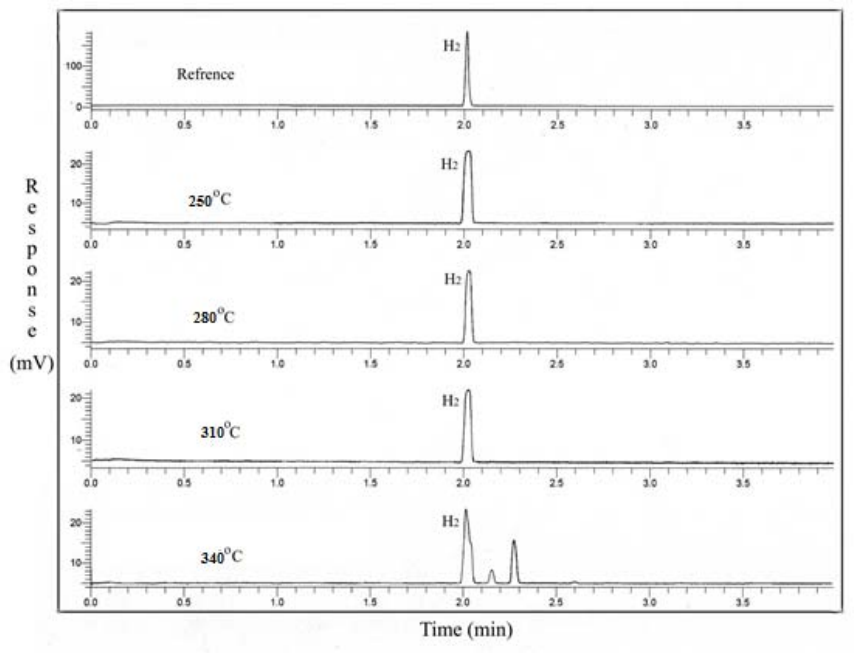

Fig. 4. Pure and evolved hydrogen spectra at 250, 280, 310 and 340

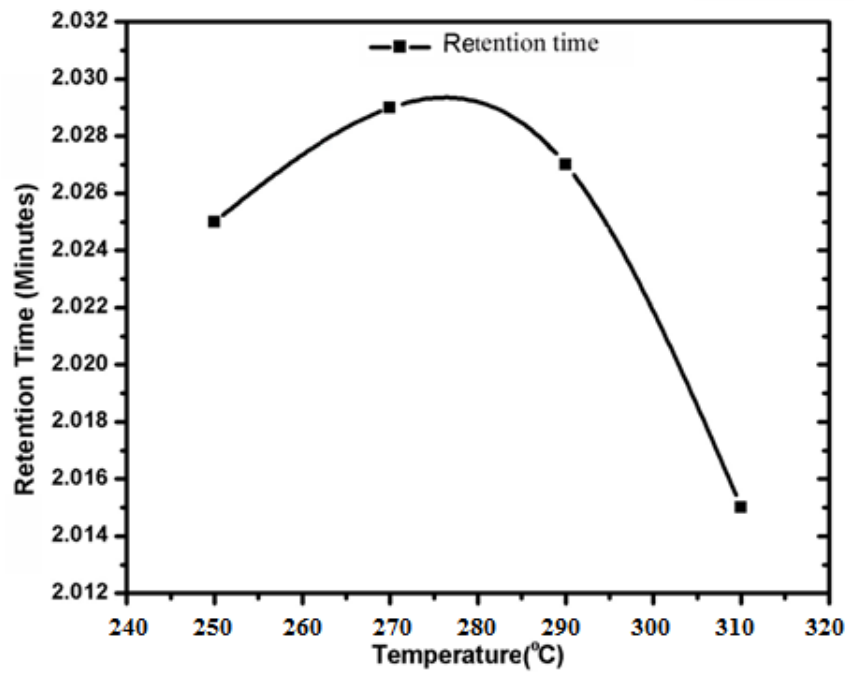

Fig. 5. Retention time of evolved hydrogen versus temperature of reactor

The variation of hydrogen percentage with temperature of the reactor is shown in Figure 6. At temperature of $250^{\circ} \mathrm{C}$, the hydrogen percentage is found to be around $20.11 \%$. It decreases to $16.66 \%$ when the temperature rises up to $280^{\circ} \mathrm{C}$ and then increases slightly to $17.13 \%$ at $310^{\circ} \mathrm{C}$. Further slight increase in hydrogen percentage (i.e. $17.70 \%$ ) was observed when the temperature increases up to $340^{\circ} \mathrm{C}$. The maximum hydrogen percentage $(20.11 \%)$ was obtained at $250^{\circ} \mathrm{C}$ while at high temperature $\left(340^{\circ} \mathrm{C}\right)$ the maximum percent of hydrogen was still below that of $250^{\circ} \mathrm{C}$. The variation of peak height of other evolved gases with the temperature is plotted in Figure 7. The peek height starts from $18447.79 \mu \mathrm{V}$ at $250^{\circ} \mathrm{C}$ then exponentially decreases to $17133.28 \mu \mathrm{V}$ at $310^{\circ} \mathrm{C}$ where it increases rapidly at $340^{\circ} \mathrm{C}$ to reach the same peak level (i.e. $18447.79 \mu \mathrm{V}$ ) as that of $250^{\circ} \mathrm{C}$. Figure 8 depicts the impacts of temperature variations on the peak area to peak height ratio of hydrogen. It has been noticed that this ratio decreases rapidly from $2.68 \mathrm{~s}$ at $250^{\circ} \mathrm{C}$ to $2.08 \mathrm{~s}$ at $280^{\circ} \mathrm{C}$, and then increases to a value of $2.38 \mathrm{~s}$ at $310^{\circ} \mathrm{C}$ where it slightly 
decreases again to $2.34 \mathrm{~s}$ at $340^{\circ} \mathrm{C}$. Although there is little decrease in the peak height (i.e. $2.37 \mathrm{~s}$ ) at $310^{\circ} \mathrm{C}$, but still it is very close to the originally obtained value (i.e. $2.38 \mathrm{~s}$ ); Thus, the curve follows approximately a similar trend as that of hydrogen among the collected evolved gases except a minor decrease in peak area to height ratio at temperature of $340^{\circ} \mathrm{C}$.

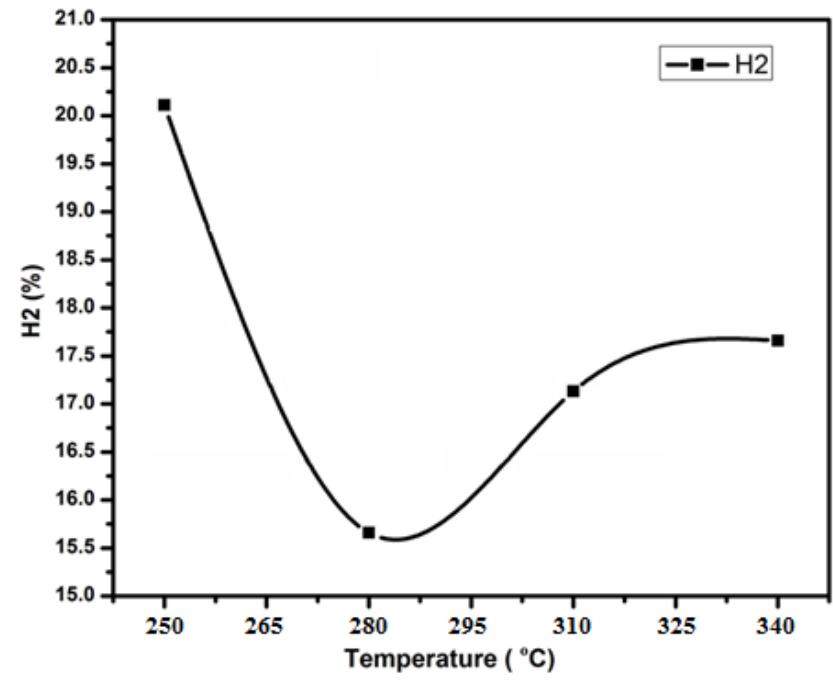

Fig. 6. Variation of hydrogen percentage of the evolved gases with increasing temperature

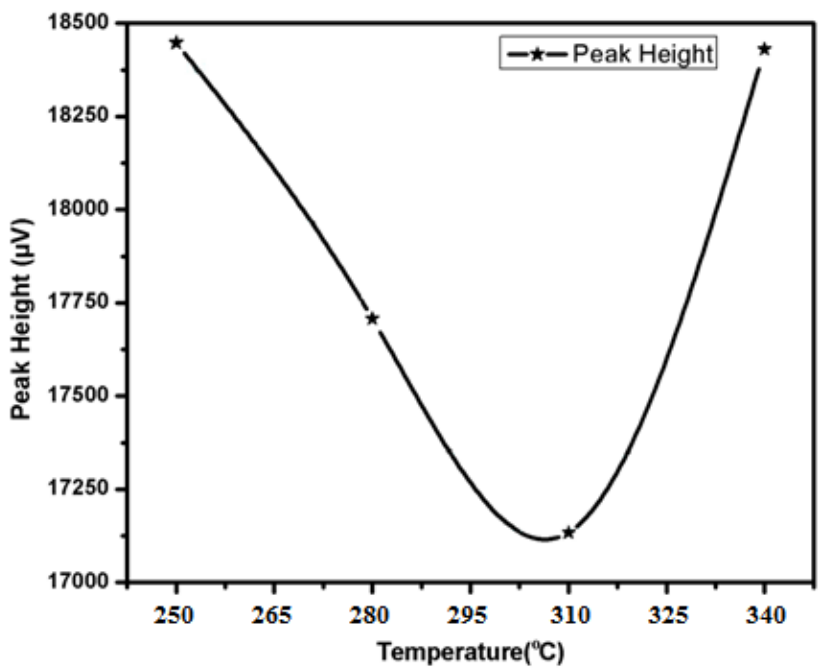

Fig. 7. Variation of peak height with the temperature of the evolved gases

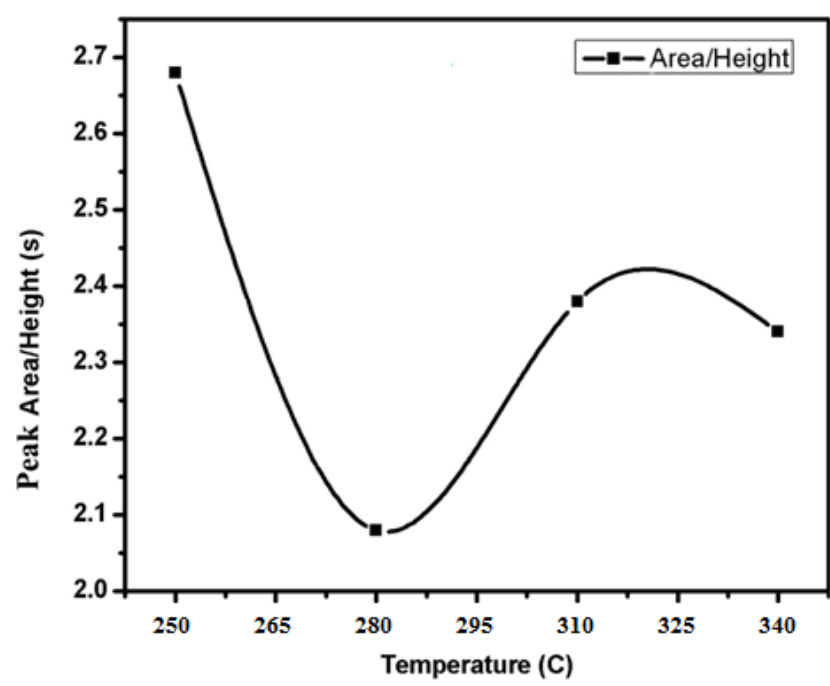

Fig. 8. Peak area/height ratio with increasing reactor temperature.

\section{CONCLUSION}

The production of hydrogen from Poly Ethylene Terephthalate (PET) using CT 434 ZSM-5 as a catalyst was experimentally investigated. Hydrogen samples of the gases evolved from the reactor at different reactor temperatures were collected and analyzed. A gas chromatography machine with a thermal conductivity detector was used to detect hydrogen in the collected gas samples. Hydrogen is observed in the spectra of gas samples at temperatures of $250^{\circ} \mathrm{C}, 280^{\circ} \mathrm{C}, 310^{\circ} \mathrm{C}$ and $340^{\circ} \mathrm{C}$ respectively. The presence of hydrogen is confirmed by comparing the spectra of evolved gas samples with the reference spectrum of pure hydrogen. The peak height values at $18430 \mu \mathrm{V}$ and $18447.79 \mu \mathrm{V}$ were noticeably very close to the values of the gas samples taken at $250^{\circ} \mathrm{C}$ and $340^{\circ} \mathrm{C}$ respectively. A similar trend is observed for peak area/height ratio and hydrogen percentage with increasing temperature of the evolved gases except a minor decrease in peak area/height ratio at the temperature of $340^{\circ} \mathrm{C}$. Maximum hydrogen percentage, around $20.11 \%$, was found in the evolved gases at temperature of $250^{\circ} \mathrm{C}$. The recorded retention time (i.e. 2.015 min) for the collected sample at $340^{\circ} \mathrm{C}$ was very close to the reference retention time (i.e. $2.014 \mathrm{~min}$ ) of pure hydrogen. This process can be developed and utilized for the production of hydrogen from solid wastes to be used as a source of green energy.

\section{ACKNOWLEDGMENT}

The author would like to thank King Abdulaziz City for Science and Technology (KACST) for funding this ongoing strategic research project under the number '10-ENV1149-06'. The author would also gratefully acknowledge King Faisal University (KFU) for furnishing the necessary research labs with cut of the edge technology and support to accomplish this work.

\section{REFERENCES}

[1] P. D. Vaidya, A. E. Rodrigues, "Insight into steam reforming of ethanol to produce hydrogen for fuel cells", Chem. Eng. J., Vol. 117, pp. 39-49, 2006 
[2] S. Ahmed, M. Krumpelt, "Hydrogen from hydrocarbon fuels for fuel cells", Int. J. Hydrogen Energy, Vol. 26, pp. 291-301, 2001

[3] A. N. Fatsikostas, D. I. Kondarides, X. E. Verykios, "Production of hydrogen for fuel cells by reforming of biomass-derived ethanol", Catal. Today, Vol. 75, No. 1-4, pp. 145-155, 2002

[4] F. Melo, N. Morlanes, "Naphtha steam reforming for hydrogen production", Catal. Today, Vol. 107-108, pp. 458-466, 2005

[5] J. W. C. Liberatori, R. Ribeiro, D. Zanchet, F. B. Noronha, J. M. C. Bueno, "Steam reforming of ethanol on supported nickel catalysts", Appl. Catal., A Gen., Vol. 327, pp. 197-204, 2007

[6] A. J. Vizcaíno, A. Carrero, J. A. Calles, "Hydrogen production by ethanol steam reforming over $\mathrm{Cu}-\mathrm{Ni}$ supported catalysis", Inter. J. Hydrogen Energy, Vol. 32, pp. 1450-1461, 2007

[7] J. G. Seo, M. H. Youn, J. C. Jung, I. K. Song, "Hydrogen production by steam reforming of liquefied natural gas (LNG) over mesoporous nickelalumina aerogel catalyst", Int. J. Hydrogen Energy, Vol. 35, pp. 67386746, 2010

[8] R. Padilla, M. Benito, L. Rodriguez, A. Serrano, G. Munoz, L. Daza, "Nickel and cobalt as active phase on supported zirconia catalysts for bio-ethanol reforming: influence of the reaction mechanism on catalysts performance", Int. J. Hydrogen Energy, Vol. 35, pp. 8921-8928, 2010

[9] S. Sa, H. Silva, L. Brandao, J. M. Sousa, A. Mendes, "Catalysts for methanol steam reformingea review", Appl. Catal. B Environ., Vol. 99, pp. 43-57, 2010

[10] A. V. Maciel, A. E. Job, W. da Nova Mussel, W. de Brito, V. M. D. Pasa, "Bio-hydrogen production based on catalytic reforming of volatiles generated by cellulose pyrolysis: An integrated process for $\mathrm{ZnO}$ reduction and zinc nanostructures fabrication", Biomass and Bioenergy, Vol. 35, No. 3, pp. 1121-1129, 2011

[11] W. Tongamp, Q. Zhang, F. Saito, "Hydrogen generation from polyethylene by milling and heating with $\mathrm{Ca}(\mathrm{OH})_{2}$ and $\mathrm{Ni}(\mathrm{OH})_{2}$ ", Int. J. hydrogen Energy, Vol. 33, pp. 4097-4103, 2008 